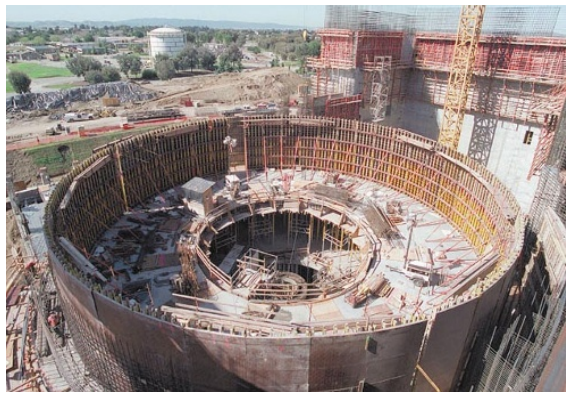

Time to come clean: critics say that the NIF's troubles go beyond clean-room difficulties.

problems. The watchdog group says its information comes from Livermore scientists worried about how the problems with the NIF are eating into other research budgets.

"The cleanliness problem is by no means the only problem," says Marylia Kelley, president of Tri Valley Care. "Some lab staff are derisive about that being the only problem."

Kelley says the optics - especially the potassium dihydrogen phosphate crystals used to generate the lasers - cannot be produced to sufficient quality and have been failing under test. The NIF specification required rapid-growth crystallization, ten times faster than that used in previous laser projects, to produce these components at the right cost.

One senior NIF scientist, speaking in Washington last week, was optimistic that the optics will be working in time. But the Livermore lab refuses to discuss the issue, and the DoE's denials of these problems are less than complete. "All of my information is that it is the complexity of the laser infrastructure, and not the optics" that have caused the cost overruns, says an official who has been speaking for Richardson on the issue.

The House of Representatives Science Committee will probably ask the General Accounting Office to investigate the NIF. The new management team and a panel of outside experts to be assembled by Richardson will determine where the project goes next.

The DoE says that the problems will have no impact on planned NIF collaborations in weapons research with the United Kingdom and France, except insofar as they delay the project's completion.

But non-weapons scientists fear that the overruns will move the NIF towards weapons research at the expense of experiments into obtaining energy from inertial confinement fusion. "It has gradually been happening anyway," says Steve Dean of Fusion Power Associates, a fusion-energy lobby group.

Observers say that the new managers are primarily weapons people. Also, a reducedspecification NIF that fails to achieve ignition - a prospect which Livermore officials privately acknowledge - will be more useful to weapons scientists than to fusion-energy researchers, who need ignition to prove the potential worth of inertial confinement fusion as an energy source. Colin Macilwain

\title{
France set to cut search for small extrasolar planets
}

\section{Paris}

Only a few years after the discovery of giant, extrasolar planets, a proposed French mission to extend the search to smaller planets in 'habitable' orbits is at risk of being axed. The project (see Nature 400, 316-317; 1999) looks set to fall foul of cuts imposed on the national space agency CNES by the science ministry.

The main scientific goal of the proposed Corot space telescope, which was due for launch in 2002, is to use seismology to study the internal structure of stars other than the Sun. But, with the telescope designed to fix the same part of the sky for 150 days at a time, astronomers built into the mission a second goal - detecting extrasolar eclipses.

Observing such eclipses would yield the orbital period and size of any planets with precision, says Frederic Bonneau, head of the mission at CNES.

But the mission, costed at a modest FF350 million (US\$55 million), including launch costs, is considered the primary target for cuts worth FF200 million to be imposed on CNES next year. The agency's science programme committee plans an emergency meeting next week to discuss Corot's future.

One member of the panel says it is likely to confirm its support for the mission, with pressure to axe Corot coming from the science

ministry, which is keen to trim France's commitments to big science programmes, and national projects in particular.

The panel member adds that space agency officials are in discussions with the ministry to try to win a reprieve for the mission. Other options to be considered at next week's meeting of the committee include postponing Corot, trying to reduce its costs, and searching for partners.

David Hughes, an astrophysicist at the University of Sheffield in the United Kingdom, is sceptical of Corot's chances of detecting planets, arguing that extrasolar eclipses are rare, even when one is looking at 6,000 stars. By definition, an eclipse would also be irreproducible, he points out. But he agrees it is a worthwhile secondary scientific objective. "If there is a reduction in brightness of the star, the data will hit them in the face anyway."

But Hughes describes Corot's main scientific goal as "super science". He argues that solar seismology has revolutionized stellar science by allowing researchers to "probe in depth" into the interior of stars, yielding information on pressure and temperature.

Because Corot would take the technique to other stars for the first time, "it is one of these space missions that has to happen," says Hughes. "If the French don't do it first, someone else will."

Declan Butler

\section{Call for UK biotechnology centre}

Sheffield

Britain's biotechnology industry last week called for the creation of a National Biotechnology Centre to boost confidence in its activities. In a report based on the findings of a government-funded delegation to the United States, the BioIndustry Association asked the government to create a centre to encourage and coordinate investment in biotechnology.

The report says that the US biotechnology industry has been encouraged by a supportive regulatory and planning environment, a responsive academic community and financial incentives.

The suggestion has already been backed by Sir Richard Sykes, chairman of Glaxo Wellcome and president of the British Association for the Advancement of Science. Speaking at the opening of the association's annual conference in Sheffield on Monday (13 September), Sykes said that such a centre was needed "if we are not to fall further behind the USA or be caught by Germany".

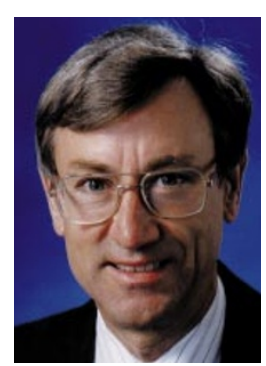

Sykes: looking for government backing.

"The Wellcome Trust is consequently looking elsewhere, including overseas, to find alternative suitable sites," he said. "A chance to create the infrastructure for exploiting our leading-edge science may have been missed."

Sykes added that Britain had fallen behind in the struggle to compete with developed and some developing countries. He said it was up to the government to create the right climate for Britain to prosper through science. 